\title{
PENGARUH SOSIOLOGI KRITIS, KREATIFITAS, DAN MENTALITASTERHADAP PENDIDIKAN AKUNTANSI
}

\author{
Ardi Hamzah \\ Fakultas Ekonomi Universitas Trunojoyo, Madura \\ JI. Raya Telang PO. BOX 2, Kamal, Bangkalan, MaduraTelp. (031) 70776914 \\ Hp. 08164264128/Email: hamzahardi@yahoo.com
}

\begin{abstract}
This research aim to test the effect of critical sosiology, creativity, and mentality on accounting education, simultaneously and partially. The respondents of the research are accounting students at Trunojoyo University. Purposive sampling technique is chosen with criteria respondents have done critical sosiology, creativity, and mentality. Data has gathered by questionnaires and documentation. Data analysis to test hypothesis is done with multiple linear regression analysis. The result of simultaneously regression indicate that critical sosiology, creativity, and mentality has significantly effect on accounting education. For examine of partially regression indicate only creativity that has significantly effect on accounting education. This shows that creativity still priority in accounting education than critical sosiology and mentality.
\end{abstract}

Keywords: critical sosiology, creativity, mentality, accounting education

\section{PENDAHULUAN}

Pendidikan akuntansi yang diajarkan di beberapa Perguruan Tinggi (PT) selama ini terkesan sebagai pengetahuan yang stagnan, mekanis, dan berorientasi pada materialitis. Stagnan, mekanis, dan materialitis ini dikarenakan pada pendidikan Akuntansi terjebak pada definisi terkait dengan akuntansi yang terkesan seakan-akan bersifat kaku dan baku. Definisi inilah membatasi daya kritis, menjauhkan dari kreatifitas serta meninggalkan nuansa mentalitas. Bercermin dari hal itu, maka pendidikan akuntansi memerlukan desekularisasi konsep pembelajaran dan kurikulum akuntansi konvensional menuju pendidikan akuntansi yang sesuai dengan nilai-nilai utama masyarakat Indonesia yang mengandung muatan sikap kritis, penuh kreatifitas, dan nuansa mentalitas.

Menurut Herring dan Bryan (2001) dalam Mulawaran (2007) menjelaskan bahwa penilaian dan keberlanjutan perubahan kurikulum pendidikan akuntansi harus memiliki kejelasan maksud dan tujuan dari kurikulum secara formal. Maksud dan tujuan dari pendidikan inilah yang menjadi substansi pendidikan akuntansi. Sistem pendidikan saat ini telah lepas dari realitas masyarakat Indonesia disebabkan sistem dan konsep pendidikan akuntansi dibawa langsung 
dari "dunia lain" (baca: Barat) yang memiliki nilai-nilai sendiri tanpa kodifikasi dan penyesuaian yang signifikan. Akuntansi merupakan produk yang dibangun dan dikembangkan dari nilai-nilai yang berkembang di masyarakat dimana akuntansi dan sistem akuntansi dikembangkan.

Akuntansi dan sistem pendidikan akuntansi memang membawa values (nilai-nilai) "sekularisasi" yang memiliki ciri utama self-interest, menekankan bottom line laba dan hanya mengakui realitas yang tercandra atau materialistik (Mulawarman, 2007). Di Indonesia pada beberapa PT, hampir semua mata kuliah Akuntansi kurang atau tidak memasukkan muatan sosiologi kritis, kreatifitas, dan mentalitas dalam kurikulum pendidikan Akuntansi. Untuk itu, pendidikan Akuntansi berbasis sosiologi kritis, kreatifitas, dan mentalitas perlu diturunkan secara lebih sistematis. Pendidikan Akuntansi berbasis sosiologi kritis, kreatifitas, dan mentalitas hanya dapat dilakukan dengan baik ketika dirumuskan dalam bentuk kurikulum yang lebih utuh. Oleh karena itu, penelitian ini menguji pengaruh sosiologi kritis, kreatifitas, dan mentalitas pada pendidikan Akuntansi untuk memperoleh bukti empirik.

\section{Rumusan Masalah}

Sesuai dengan latar belakang yang telah diungkapkan, masalah penelitian dirumuskan sebagai berikut:

Apakah muatan sosiologi kritis, kreatifitas, dan mentalitas berpengaruh terhadap pendidikan Akuntansi.

\section{Tujuan Penelitian}

Berdasarkan latar belakang dan rumusan penelitian, maka tujuan penelitian ini adalah untuk mengkaji apakah terdapat pengaruh sosiologi kritis, kreatifitas, dan mentalitas pada pendidikan Akuntansi.

\section{Kegunaan Penelitian}

Berdasar latar belakang, perumusan masalah, dan tujuan penelitian, maka kegunaan penelilitian ini sebagai berikut:

1. Memberikan masukan yang berguna untuk penyempurnaan pendidikan akuntansi, terutama berkaitan dengan penanaman dan integrasi muatan sosiologi kritis, kreatifitas, dan mentalitas dalam kurikulum akuntansi. 
2. Memberikan motivasi kepada dosen akuntansi untuk bersedia dan aktif memberikan muatan sosiologi kritis, kreatifitas, dan mentalitas dalam proses pengajaran akuntansi.

\section{TINJAUAN PUSTAKA DAN PENGEMBANGAN HIPOTESIS}

\section{Sosiologi Kritis}

Sebagai paham keilmuan, teori kritis dikembangkan dari konsepsi kritis terhadap berbagai pemikiran dan pandangan yang sebelumnya. Sedikitnya, ada dua konsepsi perihal "kritis" yang perlu diklarifikasi (Guba, 1990). Pertama, "kritis internal" terhadap analisis argumen dan metode yang digunakan dalam berbagai penelitian. Kedua, makna "kritis" dalam reformulasi masalah logika. Logika bukan semata-mata pengaturan formal dan kriteria internal dalam pengamatan, tetapi juga melibatkan bentuk-bentuk khusus pemikiran yang difokuskan pada skeptisisme dalam pengertian rasa ingin tahu terhadap institusi sosial dan konsepsi tentang realitas yang berkaitan dengan ide, pemikiran, dan bahasa melalui kondisi sosial historis.

Terdapat setidaknya enam isu pokok yang menjadi ciri paradigma kritis dalam praktik keilmuan, khususnya dalam bidang pendidikan (Salim, 2006), yaitu: 1. Prosedur, metode, dan metodologi keilmuan. 2. Perumusan kembali standar dan aturan keilmuan sebagai logika dalam konteks historis. 3. Dikotomi antara objektif dan subjektif. 4. Keberpihakan ilmu dalam interaksi sosial. 5. Pengembangan ilmu merupakan produksi nilai-nilai. 6. IImu pengetahuan (khususnya ilmu sosial) merupakan studi tentang masa lalu.

Kajian sosiologi kritis pendidikan akuntansi pada PT di Indonesia mutlak dilakukan, tetapi upaya ini sangat jarang, bahkan belum atau tidak ada usaha ke arah tersebut. Para pendidik, pengajar serta institusi yang menaunginya masih merasakan nikmatnya hegemoni pengetahuan akuntansi yang diperoleh dari dunia Barat, walaupun pada pengetahuan yang diperoleh tersebut kurang atau tidak sesuai dengan nilai-nilai yang ada pada pendidikan akuntansi di Indonesia. Ini dapat dilihat dari berbagai standar yang ada di negeri ini, semisal Prinsip Akuntansi Berterima Umum (PABU) dapat dikatakan sebagai upaya menerjemahkan PABU yang ada di negara Amerika Serikat, bukannya memberikan penalaran dan daya kritis terhadap PABU negara Amerika Serikat sebelum menerjemahkan PABU tersebut. 
PABU pada prinsipnya dilandasi oleh rerangka konseptual akuntansi, asumsi-asumsi, prinsip-prinsip, dan kendala-kendala dalam akuntansi (Weygandt dan Kieso, 2000). Landasan yang diambil dari negara yang berbeda kondisi ekonomi, sosial, dan budaya seharusnya menghasilkan PABU yang juga berbeda, walaupun perbedaan PABU antara negara tidak harus semuanya berbeda. Perbedaan landasan PABU tersebut menyebabkan adanya keberagaman dan keseragaman PABU pada setiap negara. Keberagaman dan keseragaman PABU ini dapat dikatakan sebagai sesuatu yang lumrah. Bukankah rasio sebagai pembentukan $\mathrm{PABU}$ sebetulnya tidak netral dan ahistoris sebagaimana dikatakan oleh Immanuel Kant. Ketidaknetralan rasio ini dan ahistorisnya ini yang membuat adanya PABU menjadai beragam di berbagai negara dikarenakan pengaruh dari kondisi ekonomi, sosial, dan budaya yang ada di negara tersebut. Untuk itu, pendidikan akuntansi di negara ini harus mengkaji dan mengkritisi standar yang sudah ada, walaupun berjalan secara perlahanlahan. Kritik adalah negasi atau dialektika, yaitu menegasikan atau mengingkari rintangan-rintangan yang membelenggu para pendidik dan pelajar Akuntansi selama ini. Kritik bisa pula pembebasan individu, masyarakat, dan negara dari irasionalitas menjadi rasionalitas dan dari ketidaksadaran menjadi kesadaran (Habermas, 2005).

\section{Kreatifitas}

Agar kreatifitas itu terjadi, sesuatu di dalam diri kita harus dijadikan hidup di dalam sesuatu di luar kita. Kalau Anda mencari jiwa kreatif di suatu tempat di luar dirimu, Anda mencari di tempat yang salah. Langkah dasar dalam pemecahan masalah yang kreatif (Goleman, dkk, 2005), yaitu: (1) Tahapan pertama adalah persiapan. Pada tahap ini membiarkan imajinasi bebas, membuka diri pada apapun dan secara samar-samar relevan dengan permasalahan. Tujuannya adalah untuk mengumpulkan unsur yang tidak biasa dan tidak terduga bisa dengan sendirinya muncul berdampingan. (2) tahap kedua adalah inkubasi. Pada tahap ini merenungkan seluruh potongan yang relevan dan mendesakkan pikiran rasional ke batas terjauhnya. Pada tahap ini persoalan tersebut boleh dibiarkan mengendap. (3) Tahap ketiga adalah pencerahan. Pada tahap ini, seketika jawaban yang dicari datang entah dari mana. Inilah tahapan yang biasanya memperoleh limpahan perhatian. (4) Tahap terakhir adalah penerjemahan. Pada tahap ini mengubah wawasan menjadi tindakan. 
Menerjemahkan pencerahan ke dalam realitas membuat ide hebat lebih dari sekedar pemikiran yang berlalu.

Kreatifitas bukan sebuah kemampuan tunggal yang bisa digunakan seseorang dalam setiap aktivitas. Ada tiga bahan dasar kreatifitas (Teresa dalam Goleman dkk, 2005), yaitu: (1) keahlian dalam bidang khusus berupa ketrampilan dalam hal tertentu. Ketrampilan ini merupakan penguasaan dasar dalam suatu bidang. (2) Ketrampilan berpikir kreatif. Ketrampilan berpikir kreatif ini mencakup kemampuan untuk membayangkan rentang kemungkinan yang beragam, tekun dalam menangani persoalan, dan memiliki standar kerja yang tinggi. (3) Motivasi intrinsik, dorongan untuk melakukan sesuatu semata demi kesenangan melakukannya bukan karena hadiah atau kompensasi. Orang kreatif bukan saja terbuka terhadap segala jenis pengalaman baru, mereka mau mengambil risiko. Menemukan keberanian untuk merangkul kecemasan dan mengambil langkah selanjutnya adalah penting bagi kreatifitas jenis apa pun. Cemas adalah kaki tangan kreatifitas. Akan tetapi, mengakui kecemasan dan kemauan itu untuk mengandengnya yang penting.

Kemampuan untuk membuat keputusan intuitif merupakan bahan dasar kreativitas (Goleman, dkk, 2005). Instituisi berarti menghapuskan kontrol atas pikiran dan mempercayai visi alam tak sadar. Instuisi mempunyai keberanian sendiri karena ia berlandaskan pada kemampuan alam tak sadar untuk mengorganisasi informasi menjadi ide-ide baru yang tak terduga. Pikiran yang dipenuhi oleh kekhawatiran menganggu orang berfokus pada pekerjaan. Kecemasan semacam ini merupakan pembunuh kreativitas. Bulo (2002) mengidentifikasi salah satu keluaran dari proses pengajaran Akuntansi adalah kemampuan intelektual yang terdiri dari ketrampilan teknis dasar akuntansi dan kapasitas untuk berfikir kritis dan kreatif.

\section{Mentalitas}

Ketangguhan pribadi menurut (Agustian, 2006) adalah ketika seseorang berada pada posisi telah memiliki pegangan/prinsip hidup yang kokoh dan jelas. Seseorang bisa dikatakan tangguh, apabila ia telah memiliki prinsip yang kuat sehingga tidak mudah terpengaruh oleh lingkungannya yang terus berubah dengan cepat. la tidak menjadi korban dari pengaruh lingkungan yang dapat mengubah prinsip hidup atau cara berpikirnya. Orang yang telah memiliki prinsip hidup yang kuat, ia akan mampu untuk mengambil suatu keputusan yang 
bijaksana dengan menyelaraskan prinsip yang dianut dengan kondisi lingkungannya tanpa harus kehilangan pegangan hidup, memiliki prinsip dari dalam diri keluar bukan dari luar ke dalam dan mampu mengendalikan pikirannya sendiri ketika berhadapan dengan situasi yang sangat menekan. Orang yang memiliki ketangguhan pribadi tidak akan pernah sakit hati karena ia sendiri tidak mengijinkan hatinya untuk disakiti dan ia mampu untuk memilih respon atau reaksi yang sesuai dengan prinsip yang dianutnya. la mampu keluar dari dalam diri untuk melihat dirinya sendiri dari luar sehingga mampu bersikap adil dan terbuka pada dirinya juga orang lain.

Kunci rahasia menjalin hubungan sosial dengan orang lain adalah memahami orang lain atau mempunyai rasa empati dengan memahami seluk beluk hati kita sendiri. Menurut Robert Levenson dalam Agustian (2006) memahami suara hati diri yang berbanding lurus terhadap pemahaman emosi orang lain. Bahwa memahami perasaan, motivasi serta keinginan orang lain sesungguhnya mengacu pada pemahaman suara hati diri kita sendiri.

Kurikulum akuntansi program sarjana (S1) memberikan muatan mentalitas yang mencakup moral dan etika pada mata kuliah pengembangan kepribadian (MKPK) yang pada umumnya mencakup mata kuliah agama, kewarganegaraan, dan etika. Muatan moral dan etika pada kurikulum MKPK tersebut masih dirasakan kurang. Selain itu, muatan mentalitas juga masih sedikit atau belum diberikan pada kuliah tersebut. Sedikitnya porsi muatan mentalitas yang diberikan pada MKPK akan menyebabkan pengajaran mata kuliah tersebut kurang berguna pada anak didik. Hal ini dikarenakan setelah menempuh mata kuliah tersebut, muatan mentalitas akan perlahan-lahan pudar atau dilupakan. Apalagi muatan mentalitas tidak ditanamkan atau disisipkan juga pada mata kuliah lanjutan. Pudar atau tereliminasinya muatan mentalitas ini tidak terlepas dari pembatasan peristiwa atau kejadian yang bersifat ekonomi. Unsur non ekonomi pada pendidikan Akuntansi kurang begitu diperhatikan. Pendidikan Akuntansi yang diajarkan kepada para mahasiswa lebih banyak menekankan dan berkutat pada aktiva, kewajiban, ekuitas, pendapatan, dan biaya. Kesemuanya itupun selalu diukur dengan ukuran moneter. Ketiadaan muatan mentalitas pada pendidikan Akuntansi menjadikan ilmu ini tanpa adanya spirit kejiwaan dan "kering" akan nilai-nilai kasih, sayang, keadilan, dan kejujuran. Pendidikan Akuntansi seakan-akan mengisi otak ini dengan pengetahuan logika materi. 
Wyatt (2004) dalam Yulianti dan Fitriany (2005) menyebutkan bahwa kelemahan yang terdapat pada akuntan adalah keserakahan individu dan korporasi, pemberian jasa yang mengurangi independensi, sikap terlalu 'lunak' pada klien dan peran serta dalam menghindari aturan akuntansi yang ada. Untuk menghindari hal-hal tersebut, akuntan pendidik seharusnya memberikan perhatian yang lebih besar dalam pendidikan akuntansi atas dua hal, yaitu apresiasi terhadap profesi akuntan dan apresiasi mengenai dilema etika (ethical dilemmas). Hal ini dapat dituangkan dalam bentuk mata ajaran, metode pengajaran sampai ke penyusunan kurikulum yang berlandaskan nilai-nilai etika dan moral. Wulandari dan Sularso (2002) yang melakukan penelitian di Surakarta dengan sampel mahasiswa dan akuntan pendidik. Hasil penelitiannya menunjukkan bahwa $84,38 \%$ menyatakan kurikulum program studi akuntansi belum cukup memberikan muatan etika untuk bekal mahasiswa terjun ke dunia kerja. Untuk responden yang menyatakan tidak cukup muatan etika menyarankan agar: (1) diperluas dengan mengintegrasikan ke mata kuliah tertentu (46,9,52\%), (2) diperluas dengan mengintegrasikan ke semua mata kuliah $(29,10)$, (3) ditambah sebagai mata kuliah tersendiri $(18,52)$, dan pendapat lain (5,56\%). Penelitian Wulandari dan Sularso (2002) selaras dengan hasil penelitian (Ludigdo dan Machfoedz, 1999) yang mengungkapkan muatan etika dalam kurikulum pendidikan Akuntansi belum cukup dan sebagian besar responden menyarankan untuk mengintegrasikan ke mata kuliah tertentu.

\section{Pendidikan Akuntansi}

Konsep pendidikan akuntansi di Amerika Serikat telah menjadi rujukan utama pendidikan akuntansi di Indonesia. Bila ditelusuri lebih jauh, konsep pendidikan di Amerika Serikat merupakan hasil evolusi sistem pengembangan pendidikan yang terangkum dalam American Accounting Association's Bedford Committee Report, Perspective on Education dari Akuntan Publik "The Big 8" yang dimotori Arthur Andersen serta yang paling akhir dari Position and Issues Statement of the Accounting Education Change Commision mulai tahun 1990 sampai 1995. Dari hasil evolusi pendidikan akuntansi menurut Carr dan Matthews (2004) dalam Mulawarman (2007) pengetahuan yang dibutuhkan untuk akuntan terdiri dari pengetahuan umum, organisasi, bisnis, dan akuntansi. Prakarsa (1996) menyatakan bahwa proses belajar mengajar pada pendidikan tinggi akuntansi hendaknya dapat mentransformasikan peserta didik menjadi lulusan yang lebih 
utuh sebagai manusia. Selama itu pula sebenarnya telah terjadi perubahanperubahan dalam kurikulum pendidikan, tetapi hal itu dipandang oleh Albert dan Sack (2000) dalam Mulawarman (2007) sebagai perubahan yang tidak substansial.

Ketiadaan perubahan yang substansial tersebut, dikarenakan kurikulum Akuntansi hanya berkutat pada definisi, prosedur, metode bukannya pada kajian kritis, kreatifitas, dan mentalitas. Ironisnya, ketiadaan perubahan yang substansial tersebut dijadikan pegangan dan ditiru oleh negara-negara lain yang berpola sama untuk mengikuti pendidikan yang diajarkan di dunia Barat. Oleh karena itu, pendidikan di Indonesia tidak harus ikut dalam arus pusaran pendidikan yang persis sama dengan pendidikan di Barat. Pendidikan akuntansi di Indonesia adalah sistem dan konsep dasar pendidikan akuntansi yang seharusnya merupakan citra realitas ekonomi, sosial, dan budaya masyarakat Indonesia itu sendiri. Sistem pendidikan akuntansi seharusnya dikembangkan sesuai dengan UUD 1945 dan UU Sisdiknas 2003, yaitu pendidikan yang menjadi media untuk mewujudkan suasana belajar dan proses pembelajaran sehingga tumbuh potensi holistik dirinya yang memiliki kekuatan spiritual, pengendalian diri, kepribadian, kecerdasan, akhlak mulia serta ketrampilan yang diperlukan bagi dirinya, masyarakat, bangsa dan negara (Mulawarman, 2007). Menurut Gaa dan Thorne (2004) dalam Yulianti dan Fitriany (2005) mengatakan bahwa pendidikan akuntansi selama ini memfokuskan pada dimensi pilihan kebijakan, tetapi tidak memperhatikan nilai dan kredibilitas yang mempengaruhi pilihan tersebut. Pada dasarnya akuntan memilih tindakan berdasarkan nilai yang ada dalam pikiran mereka.

\section{Pengembangan Hipotesis}

Berdasarkan masalah yang dirumuskan dan kajian teoritis, maka hipotesis penelitian yang diajukan adalah sebagai berikut:

$\mathrm{H} 1$ : Pemberian muatan sosiologi kritis dalam proses belajar mengajar berpengaruh terhadap pendidikan akuntansi.

$\mathrm{H} 2$ : Pemberian muatan kreatifitas dalam proses belajar mengajar berpengaruh terhadap pendidikan akuntansi.

H3: Pemberian muatan mentalitas dalam proses belajar mengajar berpengaruh terhadap pendidikan akuntansi. 
H4: Pemberian muatan sosiologi kritis, kreatifitas, dan mentalitas dalam proses belajar mengajar berpengaruh terhadap pendidikan akuntansi.

\section{Metodolodi Penelitian}

Penelitian ini dilakukan pada Fakultas Ekonomi Universitas Trunojoyo dengan sasaran mahasiswa program studi akuntansi. Pengambilan sampel dilakukan dengan teknik purposive sampling dengan kriteria responden yang pernah mengambil mata kuliah sosiologi kritis, kreatifitas, dan mentalitas. Pengumpulan data primer dilakukan dengan mengumpulkan responden dalam suatu ruangan kemudian diberi kuisioner untuk diisi dan dikembalikan pada saat itu juga. Kuisioner yang disebar sebanyak 75 namun hanya 71 kuisioner yang memenuhi syarat untuk dianalisis.

Analisis data meliputi pengujian instrumen berupa uji validitas dan reliabilitas, uji asumsi klasik dan pengujian hipotesis yang dilakukan dengan program SPSS 11.5 for Windows. Pengujian hipotesis penelitian ini dilakukan dengan analisis regresi berganda yang persamaannya sebagai berikut:

$$
P A=\alpha+\beta 1 S K+\beta 2 K+\beta 3 M+\varepsilon t
$$

dimana:

$$
\begin{array}{ll}
\mathrm{PA} & =\text { Pendidikan Akuntansi } \\
\mathrm{SK} & =\text { Sosiologi Kritis } \\
\mathrm{K} & =\text { Kreatifitas } \\
\mathrm{M} & =\text { Mentalitas } \\
\text { \&t } & =\text { Error term }
\end{array}
$$

\section{Definisi Operasional dan Pengukuran Variabel}

Untuk memberikan pemahaman yang lebih spesifik terhadap variabel penelitian, maka variabel - variabel tersebut didefinisikan secara operasional sebagai berikut:

1. Pendidikan akuntansi adalah prosedur, metode, materi serta model yang diberikan oleh pendidik kepada anak didik dalam proses belajar mengajar di kelas. Variabel ini diperoleh dengan kuisioner yang terdiri dari empat item yang mengandung prosedur, metode, materi serta model pendidikan akuntansi dalam proses belajar mengajar di kelas. 
2. Sosiologi Kritis adalah upaya membangkitkan kemampuan seseorang untuk bersikap kritis dan melakukan perubahan di lingkungannya yang positif. Variabel ini diperoleh dengan kuisioner yang terdiri dari 9 item berupa renungan ide-ide, pertautan pengetahuan dan kepentingan, rasio sebagai alat analisa, mental lebih penting daripada kehidupan material, pembagian status dalam pengetahuan, irasional menjadi rasional dan ketidaksadaran menjadi kesadaran, tindakan komunikasi dan interaksi, kebenaran tidak mesti melalui konsesus, mengikatkan rasional pada hati nurani.

3. Kreatifitas adalah kemampuan yang dimiliki oleh seseorang untuk mewujudkan suatu ide baru. Kemampuan tersebut dapat diperoleh dari akal pikiran dan juga dari kemampuan intuitif. Variabel ini diperoleh dengan kuisioner yang terdiri dari 9 item berupa pikiran, sikap, dan tindakan yang positif, tindakan penuh dengan risiko, mengatasi stress, pelanggaran aturan, membuat asumsi-asumsi, menanggalkan logika, merasa diri kreatif, mengaitkan sesuatu hal dengan hal lain, memilah dan memilih sesuatu.

4. Mentalitas adalah dimensi kecerdasan manusia, mengenal fitrah manusia, menemukan suara hati manusia melalui kebebasan untuk memilih serta hukum alam dan prinsip-prinsipnya. Variabel ini diperoleh dengan kuisioner yang terdiri dari 7 item berupa dimensi kecerdasan manusia, keunggulan kecerdasan spiritual, sifat dasar manusia, ketangguhan pribadi, ketangguhan sosial, ketangguhan hubungan manusia -alam, membangun ketangguhan dengan sifat kasih, sayang, dan adil.

\section{Metode Analisis}

Berdasarkan pada hipotesis yang diajukan, maka metode analisis yang digunakan dengan regresi berganda. Sebelum dilakukan pengujian regresi berganda dilakukan pengujian validitas dan reliabilitas pada item-item pertanyaan serta uji asumsi klasik terhadap variabel penelitian.

\section{Hasil dan Pembahasan}

\section{Hasil Pengujian Validitas dan Reliabilitas}

Hasil uji validitas dengan menghitung korelasi antara skor masing-masing butir pertanyaan dengan total skor setiap konstruknya. Hasil pengujian menunjukkan validitas pada skor masing-masing butir dengan skor total. Untuk pengujian reliabilitas dengan menggunakan teknik Cronbach alpha. Hasil 
pengujian menunjukkan data kuisioner adalah reliabel. Seperti tampak pada table berikut:

Tabel 1: Hasil Pengujian Reliablitas dan Validitas

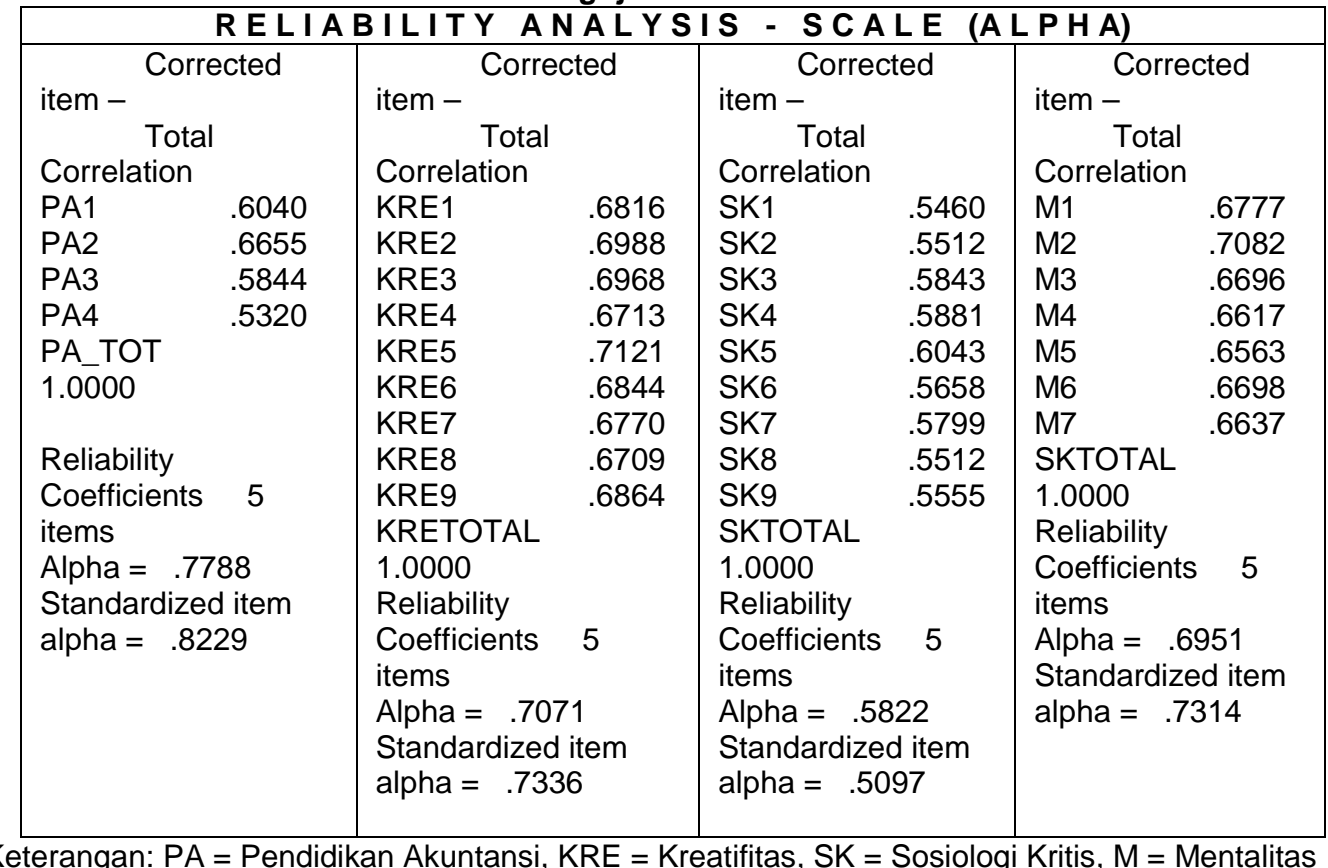

\section{Hasil Uji Asumsi Klasik}

Hasil uji asumsi klasik meliputi normalitas, otokorelasi, multikolinearitas, dan heteroskedastisitas. Hasil pengujian normalitas menunjukkan nilai signifikansi sebesar 0,904. Nilai ini jauh diatas 0,01 yang menunjukkan bahwa data dalam penelitian ini adalah normal. Pengujian otokorelasi dengan menggunakan Durbin - Watson. Hasil pengujian menunjukkan nilai DurbinWatson sebesar 2,038. Nilai ini terletak diantara du dan 4 - du yang menunjukkan tidak adanya otokorelasi. Untuk pengujian multikolinearitas dengan melihat nilai Variance Inflation Factor (VIF) dan tolerance value, bila nilai VIF kurang dari 10 dan nilai tolerance value lebih besar dari 0,1, maka tidak terjadi multikolinearitas antar variabel independen. Hasil pengujian menunjukkan nilai VIF kurang dari 10 dan nilai tolerance value lebih besar dari 0,1. Pada pengujian heteroskedastisitas dengan menggunakan uji glejser menunjukkan nilai signifiknasi sebesar 0,163. Ini menunjukkan bahwa tidak terdapat heteroskedastisitas pada data penelitian. Lebih jelasnya tampak pada table beriku: 
Tabel 2: Hasil Pengujian Normalitas dan Heteroskedastisitas One-Sample Kolmogorov-Smirnov Test

\begin{tabular}{|ll|r|}
\hline & & \multicolumn{2}{|c|}{$\begin{array}{c}\text { Unstandardized } \\
\text { Residual }\end{array}$} \\
\hline $\mathrm{N}$ & Mean & 71 \\
Normal & & .0000000 \\
Parameters(a,b) & Std. Deviation & .74286515 \\
& Absolute & .067 \\
Most Extreme & & .067 \\
Differences & Positive & -.037 \\
& Negative & .568 \\
Kolmogorov-Smirnov Z & & .904 \\
Asymp. Sig. (2-tailed) & & \\
\hline
\end{tabular}

a Test distribution is Normal.

b Calculated from data.

Tabel 3: Hasil Pengujian Normalitas dan Heteroskedastisitas ANOVA(b)

\begin{tabular}{|l|l|r|r|r|r|c|}
\hline Model & & $\begin{array}{c}\text { Sum of } \\
\text { Squares }\end{array}$ & \multicolumn{1}{c|}{$\mathrm{df}$} & $\begin{array}{c}\text { Mean } \\
\text { Square }\end{array}$ & \multicolumn{1}{c|}{$\mathrm{F}$} & Sig. \\
\hline 1 & Regression & 1.132 & 3 & .377 & 1.763 & $.163(\mathrm{a})$ \\
& Residual & 14.340 & 67 & .214 & & \\
& Total & 15.472 & 70 & & & \\
\hline
\end{tabular}

a Predictors: (Constant), Mentalitas Rata-rata, Kreatif Rata-rata, SK rata-rata

b Dependent Variable: Residu

\section{Hasil Pengujian Regresi}

Pengujian regresi dilakukan dengan pengujian regresi parsial dan pengujian simultan. Hasil pengujian regresi, baik secara parsial maupun simultan dapat dilihat pada dibawah ini.

Tabel 4: Model Summary(b)

\begin{tabular}{l|l|r|r|r|r|}
\hline Model & $\mathrm{R}$ & $\mathrm{R}$ Square & $\begin{array}{c}\text { Adjusted } \\
\text { R Square }\end{array}$ & $\begin{array}{r}\text { Std. Error of } \\
\text { the Estimate }\end{array}$ & $\begin{array}{c}\text { Durbin- } \\
\text { Watson }\end{array}$ \\
\hline 1 & $.377(\mathrm{a})$ & .142 & .103 & .759 & 2.038 \\
\hline
\end{tabular}


Tabel 5: Coefficients

Coefficients(a)

\begin{tabular}{|c|c|c|c|c|c|c|c|c|c|c|c|}
\hline \multirow[t]{2}{*}{$\begin{array}{l}\text { Mod } \\
\text { el }\end{array}$} & & \multicolumn{2}{|c|}{$\begin{array}{l}\text { Unstanda } \\
\text { rdized } \\
\text { Coefficien } \\
\text { ts }\end{array}$} & \multirow[t]{2}{*}{$\begin{array}{c}\text { Standar } \\
\text { dized } \\
\text { Coefficie } \\
\text { nts } \\
\end{array}$} & \multirow[t]{2}{*}{$\mathrm{t}$} & \multirow[t]{2}{*}{ Sig. } & \multicolumn{3}{|c|}{ Correlations } & \multicolumn{2}{|c|}{$\begin{array}{l}\text { Collinearity } \\
\text { Statistics }\end{array}$} \\
\hline & & B & Erro & & & & $\begin{array}{l}\text { Zero- } \\
\text { order }\end{array}$ & $\begin{array}{c}\text { Partia } \\
\text { I }\end{array}$ & Part & $\begin{array}{l}\text { Toler } \\
\text { ance }\end{array}$ & VIF \\
\hline \multirow[t]{4}{*}{1} & $\begin{array}{l}\text { (Const } \\
\text { ant) }\end{array}$ & $\begin{array}{r}1.3 \\
49\end{array}$ & 639 & & $\begin{array}{r}2.1 \\
10\end{array}$ & $\begin{array}{r}.03 \\
9\end{array}$ & & & & & \\
\hline & $\begin{array}{l}\text { SK } \\
\text { rata- } \\
\text { rata }\end{array}$ & $\begin{array}{r}- \\
.02 \\
0\end{array}$ & .293 & -.009 & $\begin{array}{r}- \\
.06 \\
8\end{array}$ & $\begin{array}{r}.94 \\
6\end{array}$ & . 118 & -.008 & $\begin{array}{r}- \\
.00 \\
8\end{array}$ & .822 & $\begin{array}{r}1.2 \\
17\end{array}$ \\
\hline & $\begin{array}{l}\text { Kreatif } \\
\text { Rata- } \\
\text { rata } \\
\text { Mental }\end{array}$ & $\begin{array}{r}.63 \\
3\end{array}$ & .201 & .388 & $\begin{array}{r}3.1 \\
52\end{array}$ & $\begin{array}{r}.00 \\
2\end{array}$ & .374 & .359 & $\begin{array}{r}.35 \\
7\end{array}$ & .845 & $\begin{array}{r}1.1 \\
84\end{array}$ \\
\hline & $\begin{array}{l}\text { itas } \\
\text { Rata- } \\
\text { rata }\end{array}$ & $\begin{array}{r}- \\
.08 \\
7\end{array}$ & .259 & -.040 & $\begin{array}{r}.33 \\
4\end{array}$ & $\begin{array}{r}.74 \\
0\end{array}$ & .060 & -.041 & $\begin{array}{r}.03 \\
8\end{array}$ & .876 & $\begin{array}{r}1.1 \\
41\end{array}$ \\
\hline
\end{tabular}

a Dependent Variable: PA rata-rata

\section{Hasil Pengujian Regresi}

Hasil pengujian regresi parsial menunjukkan bahwa sosiologi kritis tidak berpengaruh secara signifikan pada pendidikan akuntansi. Ini ditunjukkan dengan nilai t-hitung sebesar -0,068 dan nilai signifikansi sebesar 0,946. Pengaruh sosiologi kritis yang tidak signifikan pada pendidikan akuntansi menunjukkan bahwa pendidikan akuntanso belum adanya perubahan akuntansi. Dengan kata lain, pendidikan akuntansi masih terhegemoni dengan pendidikan akuntansi di luar Indonesia (Baca: Barat). Selain itu, juga menunjukkan bahwa proses pendidikan akuntansi kurang adanya ide-ide dari perenungan, kurang mempertautkan pengetahuan dan kepentingan berbagai pihak terkait, hanya mementingkan kepentingan pribadi atau perusahaan (materi), belum mementingkan pikiran dan mental daripada kehidupan material, masih belum terbebas dari rasionalitas dan kesadaran, lebih mementingkan konsesus (kesepakatan bersama) dalam perubahan pendidikan akuntansi serta kurang adanya pembebasan diri dari akan rasional dengan mengikatkan diri pada hati nurani.

Untuk kreatifitas menunjukkan pengaruh yang signifikan pada pendidikan akuntansi. Ini dapat dilihat dari nilai t-hitung sebesar 3,152 dan nilai signifikansi sebesar 0,002. Dengan kata lain, kreatifitas berpengaruh secara signifikan pada tingkat $0,01 \%$ pada pendidikan akuntansi. Pengaruh kreatifitas secara signifikan 
terhadap pendidikan akuntansi menunjukkan bahwa pendidikan akuntansi sarat dengan kreatifitas. Salah satu "kreatifitas" pada pendidikan akuntansi yaitu dengan adanya manajemen laba (earning manajemen) yang mengelola sisi aktiva (piutang, persediaan, aktiva tetap berhubungan dengan depresiasi) yang terkait dengan laba. Selain itu, pendidikan akuntansi juga menunjukkan adanya pikiran, sikap, dan tindakan posistif, tindakan penuh dengan risiko yang ada, mengatasi tekanan, mendorong membuat regulasi menjadi lebih baik, adanya asumsi-asumsi dari pikiran dan tindakan, sudah mulai menanggalkan logika, mengaitkan sesuatu hal dengan hal lain yang mampu membuat nilai tambah dan berdaya guna serta mampu memilah dan memilih bagia dari sesuatu untuk dibuat sesuatu yang berdaya guna dan bernilai tambah.

Untuk mentalitas menunjukan tidak berpengaruh secara signifikan pada pendidikan akuntansi. Ini ditunjukkan dengan nilai t-hitung sebesar -0,334 dan nilai signifikansi sebesar 0,740 . Hasil penelitian ini mendukung penelitian yang dilakukan oleh Wulandari dan Sularso (2002) serta Ludigdo dan Machfoedz (1999). Hasil penelitian ini menunjukkan bahwa pendidikan akuntansi belum mementingkan dimensi kecerdasan berupa kecerdasan intelektual, emosional, dan spiritual serta masih mengunggulkan kecerdasan intelektual dibanding dua kecerdasan lainnya, belum memiliki sifat dasar yaitu kasih, sayang, adil, dan syukur, belum adanya keseimbangan ketangguhan berupa ketangguhan pribadi, ketangguhan sosial, dan ketangguhan hubungan manusia-alam.

Hasil penelitian secara parsial yang menunjukkan hanya kreatifitas berpengaruh signifikan terhadap pendidikan akuntansi, menempatkan kreatifitas kreatifitas sebagai variabel yang berpengaruh dominan terhadap pendidikan akuntansi. Pengaruh dominan kreatifitas terhadap pendidikan akuntansi tersebut erat kaitannya dengan prosedur, metode, materi, dan model proses belajar mengajar yang ada. Temuan penelitian ini yang menempatkan kreatifitas sebagai variabel yang berpengaruh dominan terhadap pendidikan akuntansi juga erat kaitannya dengan keberadaan mahasiswa sebagai responden penelitian ini. Mahasiswa sebagai anak didik dari suatu perguruan tinggi akan terdidik berdasarkan proses pendidikan yang berlangsung dalam lembaga pendidikan tersebut. Proses pendidikan yang berlangsung pada pendidikan akuntansi selama ini masih sangat menekankan pada aspek ketrampilan. Sementara pembentukan sikap, perilaku, dan tindakan yang menyangkut daya kritis (perubahan) dan mentalitas masih sangat kurang diperhatikan. Oleh karena itu, 
mahasiswa sebagai anak didik cenderung menonjol dalam ketrampilan dibanding dalam pemikiran kritis untuk perubahan dan muansa mentalitas. Hal ini mendorong kreatifitas dalam penelitian ini menjadi variabel yang dominan berpengaruh terhadap pendidikan akuntansi dibandingkan dengan sosiologi kritis dan mentalitas.

Hasil pengujian regresi simultan menunjukkan bahwa sosiologi kritis, kreatifitas, dan mentalitas berpengaruh secara signifikan pada tingkat $5 \%$ terhadap pendidikan akuntansi. Ini ditunjukkan dengan nilai F-hitung sebesar 3,690 dan nilai signifikansi sebesar 0,016 . Nilai $R^{2}$ sebesar $37,7 \%$ menunjukkan bahwa sosiologi kritis, kreatifitas, dan mentalitas memberikan kontribusi sebesar $37,7 \%$ terhadap pendidikan akuntansi, sedangkan $62,3 \%$ disebabkan oleh faktorfaktor lain. Adanya pengaruh sosiologi kritis, kreatifitas, dan mentalitas secara simultan terhadap pendidikan akuntansi menunjukkan bahwa sosiologi kritis, kreatifitas, dan mentalitas bukanlah sesuatu hal yang saling bertentangan, melainkan sesuatu hal yang saling terkait satu dengan yang lain.

\section{PENUTUP}

Berdasarkan hasil penelitian dan pembahasan yang dikemukakan sebelumnya, maka dapat disimpulkan: 1. Pengujian secara simultan menunjukkan bahwa sosiologi kritis, kreatifitas, dan mentalitas berpengaruh signifikan terhadap pendidikan akuntansi. 2. Pengujian secara parsial menunjukkan bahwa hanya kreatifitas yang berpengaruh secara signifikan terhadap pendidikan akuntansi. 3. Sosiologi kritis, kreatifitas, dan mentalitas merupakan sesuatu hal yang saling terkait satu dengan hal yang lain bukannya sesuatu hal yang saling bertentangan.

Adapun saran untuk penelitian ini: 1. Bagi perguruan tinggi khususnya yang mengajarkan pendidikan akuntansi dan IAI, perlu melakukan upaya untuk mensinergikan, menyelaraskan, dan menyerasikan antara sosiologi kritis, kreatifitas, dan mentalitas bagi anak didik dan anggotanya secara komprehensif dalam pembentukan manusia yang seimbang dalam kecerdasan intelektual ,emosional dan spiritual serta ketangguhan pribadi, sosial, dan ketangguhan hubungan manusia alam. 2. Bagi peneliti selanjutnya dapat mengembangkan penelitian ini dengan membandingkan antara mahasiswa yang pernah mendapat materi sosiologi kritis, kreatifitas, dan mentalitas dengan mahasiswa lain yang 
belum mendapat ketiga meteri tersebut. Selain itu, juga mengembangkan instrumen pengukuran pada pendidikan akuntansi, sosiologi kritis, kreatifitas, dan mentalitas diluar item-item yang ada pada instrumen ini.

Pemberian muatan sosiologi kritis, kreatifitas, dan mentalitas dalam kurikulum akuntansi dapat meningkatkan daya kritis, muatan kreatifan, dan nuansa mentalitas pada diri mahasiswa. Oleh karena itu sudah waktunya pendidikan akuntansi di Indonesia memberikan dan mengintegrasikan muatan sosiologi kritis, kreatifitas, dan mentalitas secara eksplisit dalam Satuan Acara Perkulihan (SAP) pada setiap mata kuliah akuntansi sehingga "ruh" sosiologi kritis, kreatifitas, dan mentalitas merasuk pada semua mata kuliah pada pendidikan akuntansi.

\section{DAFTAR PUSTAKA}

Agger, Ben. 2006. Teori Sosial Kritis: Kritik, Penerapan dan Implikasinya. Penerbit Kreasi Wacana. Yogyakarta.

Agustian, Ary Ginanjar. 2006. Rahasia Sukses Membangun Kecerdasan Emosi dan Spiritual. Penerbit ARGA. Jakarta.

Bulo, William, E.L. 2002. Pengaruh Pendidikan Tinggi Akuntansi Terhadap Kecerdasan Emosional Mahasiswa. Skripsi FE UGM.

Buzan, Tony and Barry Buzan. 2003. The Mind Map Book. London: BBC Worldwide Limited.

Dillard, Jesse F. 1991. Accounting as a Critical Social Sciences. Accounting Auditing \& Accountability Journal. Vol. 4 No. 1.

Ghozali, Imam. 2005. Aplikasi Analisis Multivariate dengan Program SPSS. Badan Penerbit Universitas Diponegoro. Semarang..

Goleman. Daniel, Kaufman Paul, and Ray, Michael. 2005. The Creative Spirit (terjemahan). Penerbit Penerbit MLC. Bandung.

Goman, Carol Kinsey. 2001. Creativity in Business: Mengubah Gagasan Menjadi Keuntungan. (Terjemahan). Jakarta: Penerbit PPM.

Guba, Egon. 1990. The Paradig Dialog. London: Sage.

Habermas. 2005. Kritik Ideologi (terjemahan). Penerbit Galang Press. Yogyakarta. 
Hamzah, Ardi. 2007. Pendidikan Akuntansi Perspektif Sosiologi Kritis, Kreatifitas, dan Mentalitas. The First Asccounting Season: revolution of Accounting Education. Bandung.

Ludigdo, Unti dan Machfedz, Mas'ud. 1999. Persepsi Akuntansi dan Mahasiswa tentang Etika Bisnis. Jurnal Riset Akuntansi Indonesia. Vol. 1, No. 1, hal. $1-19$.

Mulawarman, Aji Dedi. 2007. Pensucian Pendidikan Akuntansi Episode Dua: Hiper View of Learning dan Implementasinya. The First Accounting Season: Revolution of Accounting Education. Bandung.

Prakarsa, Wahyudi. 1996. Transformasi Pendidikan Akuntansi Menuju Globalisasi. Konvensi Nasional Akuntansi III. Jakarta: Ikatan Akuntan Indonesia.

Quatrrone, Paolo. 2000. Constructivism and Accounting Research: Toward a Trans Discplinary Perspective. Accounting, Auditing, and Accountability Journal.

Reiter, Sara. 1997. The Ecthic of Care and New Paradigm for Accounting Practice. Accounting, Auditing, and Accountability Journal.

Richard, Osborne. 2004. Mengenal Sosiologi (terjemahan). Penerbit Gramedia. Jakarta.

Ritzer, Goodman. 2004. Teori Sosiologi Modern (terjemahan). Penerbit Gramdeia. Jakarta.

Salim, Agus. 2002. Perubahan Sosial. Penerbit PT. Tiara Wacana. Yogyakarta.

Salim, Agus.2006. Teori dan Paradigma Penelitian Sosial. Penerbit Tiara Wacana. Yogyakarta.

Sindhunata. 2004. Dilema Usaha Manusia Rasional. Penerbit Rajwali Press. Jakarta.

Triyuwono, Iwan. 2006. Perspektif, Metodologi, dan Teori Akuntansi Syariah. Penerbit PT Raja Grafindo Persada. Jakarta.

Wulandari dan Sularso. 2002. Persepsi Akuntan Pendidik dan Mahasiswa Akuntansi Terhadap Kode Etik Akuntan Indonesia: Studi Kasus di Surakarta, Perspektif. Vol 10. 7, No.2, hal. $71-87$.

Weygandt, Jerry J, Kieso, Donald E, dan Kell, Walter G. 1996. Accounting Principles. Fourth Edition. John Wiley \& Sons, Inc.

Yulianti dan Fitriany. 2005. Persepsi Mahasiswa Akuntansi Terhadap Etika Penyusunan Laporan Keuangan. Simposium Nasional Akuntansi 8 Solo. 